\title{
URBAN HEAT ISLAND IN BIAŁYSTOK
}

\section{Robert Czubaszek', Agnieszka Wysocka-Czubaszek}

1 Bialystok University of Technology, Department of Environmental Protection and Management, Wiejska 45A, 15-351 Białystok, Poland, e-mail: r.czubaszek@pb.edu.pl; a.wysocka@pb.edu.pl

Received: 2016.04.02 Accepted: 2016.06.01 Published: 2016.07.01

\begin{abstract}
The aim of the study was to investigate the formation intensity of the urban heat island (UHI) in Białystok, a relatively small city in north-eastern Poland. The UHI development was determined on the basis of meteorological data obtained from two weather stations of the Regional Inspectorate for Environmental Protection in Białystok, one located in the city center, and the other on its outskirts. The measurements of temperature gathered by automobile traverses along streets running from the city limits through the center were carried out in order to provide spatial diversity of the studied phenomenon. The results indicated that UHI in Bialystok is very clear. The intensity of this phenomenon changes in the daily cycle, with the peak in the evening. During the year the heat island is the most pronounced in the spring.
\end{abstract}

\section{INTRODUCTION}

Cities are considered as areas in which the local climate is modified significantly. Urban areas with high traffic volumes and dense residential and commercial buildings greatly affect the local air quality and energy balance. Studies on the modification of local climate by urban development have been conducted for many years and the elevation of air temperatures in city centers is a phenomenon that has been recorded since 1833 [Oke 1982]. Other meteorological parameters have been analyzed less intensively. The investigations of urban impacts on the wind field have mainly focused either on numerical simulation of mesoscale wind patterns [Draxler 1986] or the wind distribution within urban canyons [Nakamura and Oke 1988]. Comparative studies of observed urban-rural wind velocity differences are less common, but they show the decrease of wind speed in urban areas [Fortuniak et al. 2006]. The studies on humidity are sparse but they also demonstrate differences between rural and urban areas [Fortuniak et al. 2006].

Anthropogenic alterations to the earth's surface cause microclimatic changes that result in the formation of the phenomenon which is called urban heat island (UHI) [Landsberg 1981]. An
UHI can be visualized as a dome of warm air over built-up areas of the cities [Emmanuel 2005]. The heat that is absorbed during the day by the urban area is re-emited during night and creates temperature differences between urban and rural areas [Asimakopoulos et al. 2001]. This elevation of air temperatures of cities can be significant, like in the center of Baltimore, where ground level air temperatures were $5-10{ }^{\circ} \mathrm{C}$ warmer than residential or forested and agricultural areas [Brazel et al. 2000]. This increase of air temperature in urban areas is caused mainly by the conversion of natural land into roads and buildings, which changes the albedo and heat capacity of an area in comparison with rural landscape [Oke 1982].

The high thermal conductivity of buildings and other man-made structures as well as geometry of city surfaces and low evapotranspiration rates contribute significantly in elevation of air temperature in cities [Taha et al. 1991]. Other contributors are heat from building ventilation and vehicle traffic [Fan and Sailor 2005]. All those sources change with time and space affecting the spatial and temporal variability of air temperature in cities.

Land-cover types common to urban areas, such as dark-coloured pavement, brick, and asphalt, absorb large amounts of incident radiation 
during the day and release it during the evening, causing maximum temperature differences between urban and rural environments to occur usually at night [Chandler 1965; Oke and East 1971; Landsberg 1981; Roth 2007]. The replacement of the previous pervious surfaces by built up surfaces significantly reduces the cooling effect of the green vegetation through its natural evapotranspiration processes [Douglas 1983]. Introduction of green spaces as well as less dense buildings in urban areas results in better ventilation which may cause significant decrease of UHI intensity [Gołaszewski et al. 2007].

It is commonly thought that the intensity of UHIs depends on the local surrounding landcover characteristics of both rural and urban sites. Many studies used either fixed- or mobile-station measurements, or a combination of both, to study the relationship between land cover and the UHI. For example, Hawkins et al. [2004] used fixed stations in Phoenix, Arizona, to study the specific effects of different land-cover types in rural landscapes on ambient temperature. When compared with temperature at an urban reference, they found significant differences $\left(3.4{ }^{\circ} \mathrm{C}\right)$ in the UHI depending on cover type, with the smallest to the largest occurring between the urban reference and hardpan 'dirt', cultivated vegetation, and a mowed grass field, in this order. Hedquist and Brazel [2006] used a combination of fixed stations and mobile measurements to study the differences in temperature, also in Phoenix, Arizona, between urban, residential neighborhoods and rural landscapes for times after sundown. Their mobile data showed an average urban-rural temperature difference of $7{ }^{\circ} \mathrm{C}$ and an urban-residential neighborhood temperature difference of $3{ }^{\circ} \mathrm{C}$.

The aim of the study was to investigate the formation intensity of the urban heat island (UHI) as well as the spatial variability of this phenomenon in Białystok, a medium-size town in northeastern Poland.

\section{MATERIAL AND METHODS}

The study was carried out in the area of Białystok, a city in north-eastern Poland. It occupies an area of $102 \mathrm{~km}^{2}$ and is inhabited by 295.5 thousand people. The land use structure is dominated by built-up areas covering approximately $50 \%$ of the city area. The remaining part is agricul- tural land (approx. 29\%), forest and wooded land (approx. 19\%), land under water (approx. 1\%) and wasteland (approx. 1\%) [Statistical ... 2015].

The intensity of the urban heat island in Białystok was determined on the base of the difference in temperature measured at two weather stations operating within the State Environmental Monitoring. One of them is located in the city center, and the other on its outskirts (Figure 4). These stations measure the meteorological parameters every hour so the temperature differences between the measuring points were counted in the same way. In order to establish the UHI diurnal behavior, the arithmetic average of the obtained data for every hour were calculated. This allowed present the annual and seasonal variability of studied phenomenon.

The measurements of temperature gathered by automobile traverses along streets running from the city limits through the center were carried out in order to recognize spatial variability of the studied phenomenon. The earlier analysis of UHI development throughout the year indicated the largest UHI in spring and that is why the mobile test performed on the $10^{\text {th }}$ of May. The temperature was measured with Pt100 temperature sensor connected to the logger and mounted on the top of the passenger car. The total length of the traverse was approx. $20 \mathrm{~km}$. The vehicle speed was approx. $40-50 \mathrm{~km} \mathrm{~h}^{-1}$ and the temperature was recorded every 15 seconds. The results then were averaged for periods of one minute.

\section{RESULTS AND DISCUSSION}

The urban heat island occurs in urban areas, regardless of their size. Only the scale of this phenomenon is different. Oke [1973] and Torok et al. [2001] showed that even towns with populations of 1000 people had urban heating of about $2.2{ }^{\circ} \mathrm{C}$ compared to the nearby rural countryside. The studies conducted by Błażejczyk et al. [2006] in several cities which varies in size and population indicated the presence of UHI in the area of Warsaw as well as in the area of such a small town as Supraśl.

On the basis of the formula proposed by Oke [1973]:

$$
U H I=0.73 \log _{10}(\text { pop })
$$

where pop denotes population, for the village with a population of 10 heat island (warm bias) 
should be $0.73{ }^{\circ} \mathrm{C}$, but for the city of one million inhabitants should increase to $4.4{ }^{\circ} \mathrm{C}$. Using this model for Białystok, a city with a population of approx. 300000 obtained value is approx. $4{ }^{\circ} \mathrm{C}$.

During the studied period, the maximum value of the temperature difference between a point in the center of Białystok and a point on its outskirts was $8,2{ }^{\circ} \mathrm{C}$ at night on the $26^{\text {th }}$ of April, while the lowest value, $-1,1^{\circ} \mathrm{C}$ was found on the $21^{\text {st }}$ of September. The mean value of the temperature difference between urban and suburban areas over the studied period was equal to 2.3 ${ }^{\circ} \mathrm{C}$. The values of the monthly average are in the range $1.7-2.8{ }^{\circ} \mathrm{C}$, which proves the existence of the urban heat island throughout the year (Figure 1). Maximum of this phenomenon occurs in the summer months (May-August), while the lowest values were observed in winter. A similar scheme was observed in the case of Warsaw [Gołaszewski et al. 2007] but in Białystok, a decrease of the UHI in July has happened.

The analysis of the diurnal behavior of the urban heat island in Bialystok, determined on the basis of the whole year, showed that the clear development of this phenomenon starts approx. at 16:00, and its maximum, amounting to $2.95{ }^{\circ} \mathrm{C}$ is reached approx. at 22:00 (Figure 2). In the following hours, there is a slight decrease of UHI, which is more clearly indicated at 5.00, when it is reduced from $2.51{ }^{\circ} \mathrm{C}$ to $1,8{ }^{\circ} \mathrm{C}$ approx. at 7:00. During the day, the calculated temperature differences vary slightly, reaching minimum value $\left(1,62{ }^{\circ} \mathrm{C}\right)$ approx. at $15: 00$, when small in the beginning and more clear few hours later, increase of the UHI begins.

In every season, the urban heat island development begins at afternoon hours (15:00-16:00) (Figure 3), except autumn when UHI occurs in the hours 15:00-18:00 and after peaking at 19.00 almost linear decreases to 15:00. In other seasons in the night the UHI effect is rather stable. Slightly larger differences were found in case of the maximum value of UHI. In spring and winter the maximum values were recorded around 22:00, in the summer at 21:00, while in the autumn at 19:00. The seasons also differed in terms of value, which the maximum temperature differences have reached. It was $3.7^{\circ} \mathrm{C}$ in the spring, $3.3{ }^{\circ} \mathrm{C}$ in the summer, $2.6{ }^{\circ} \mathrm{C}$ in the autumn and $2.3{ }^{\circ} \mathrm{C}$ in the winter. The minimum values were much more aligned, within the range from $1.3{ }^{\circ} \mathrm{C}$ in autumn and winter to 1.4 ${ }^{\circ} \mathrm{C}$ in spring and summer. However, in spring and summer the minimum temperature difference occurred in the morning, but in the autumn and winter, it was observed in the afternoon.

The study on the spatial distribution of the heat island in Bialystok has shown that this phenomenon starts at the city limit and reaches its maximum in its center. During the study, the lowest temperature was recorded in the area of the Supraśl River valley located between Białystok and Wasilków town. In the Wasilków town, air temperature raised again, indicating the existence of heat island also in the case of this small town. During the experiment, a significant effect of vegetation on the temperature of air in the city was observed as rapid decrease of temperature in the vicinity of even small forested areas (Figure 4, points 7, 12 and 21).

Murphy at al. [2011] have found that 'green spaces' were ineffective in combating warming during the day, whereas tree cover and the shade it provides were successful agents in diminishing daytime warming. The forested site was the coolest on average and able to negate effects of daytime warming within the canopy layer. This effect occurs because of the absorption of incident solar radiation in the upper tree canopy, where much of the radiation is converted to latent heat via evaporative cooling, thus preventing the penetration of solar radiation to warm the soil surface and resulting in its conversion to sensible heat to the air near the ground. Grassland sites showed not only significant daytime warming, but also pronounced nighttime cooling, resulting in large diurnal temperature ranges. Canopy cover should therefore be encouraged to maintain cooler temperatures throughout the day, thus reducing expenditures on air conditioning [Murphy et al. 2011]. Although the vegetation covers could reduce the UHI intensity [Strecker and Liptan 2003], studies elsewhere has confirmed that soil moisture condition could also give same result as the green natural surfaces. For example, due to prolonged wet spell the land surface temperature has abruptly reduced and inhibit the occurrence of UHI [Lakshmi at. al 2000]. Shaharuddin and Noorazuan [2007] have shown that in spite of the urban cover increase, the UHI intensity in Selengor (Malaysia) has been reduced due to the effect of soil moisture content.

One of the factors that impacted UHI formation are synoptic effects that modify wind speed and atmospheric stability. Oke [1976] found that 


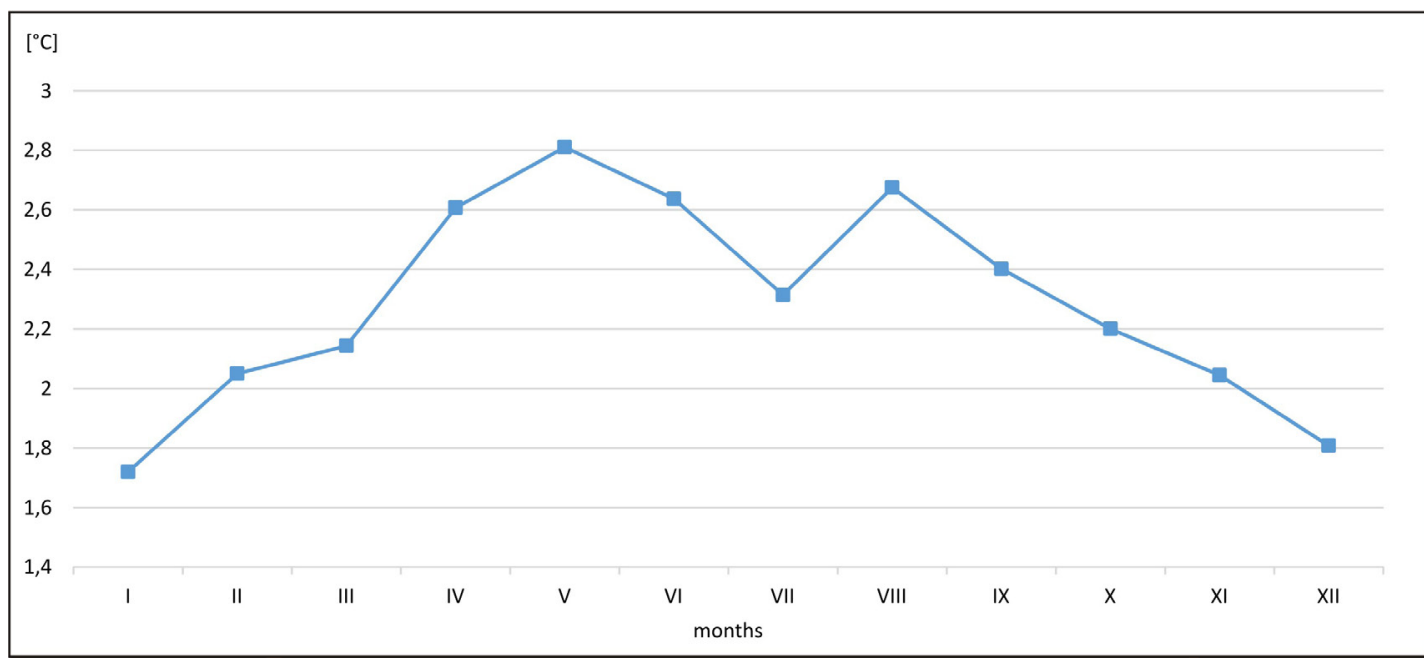

Figure 1. Average monthly temperature differences between urban and suburban area

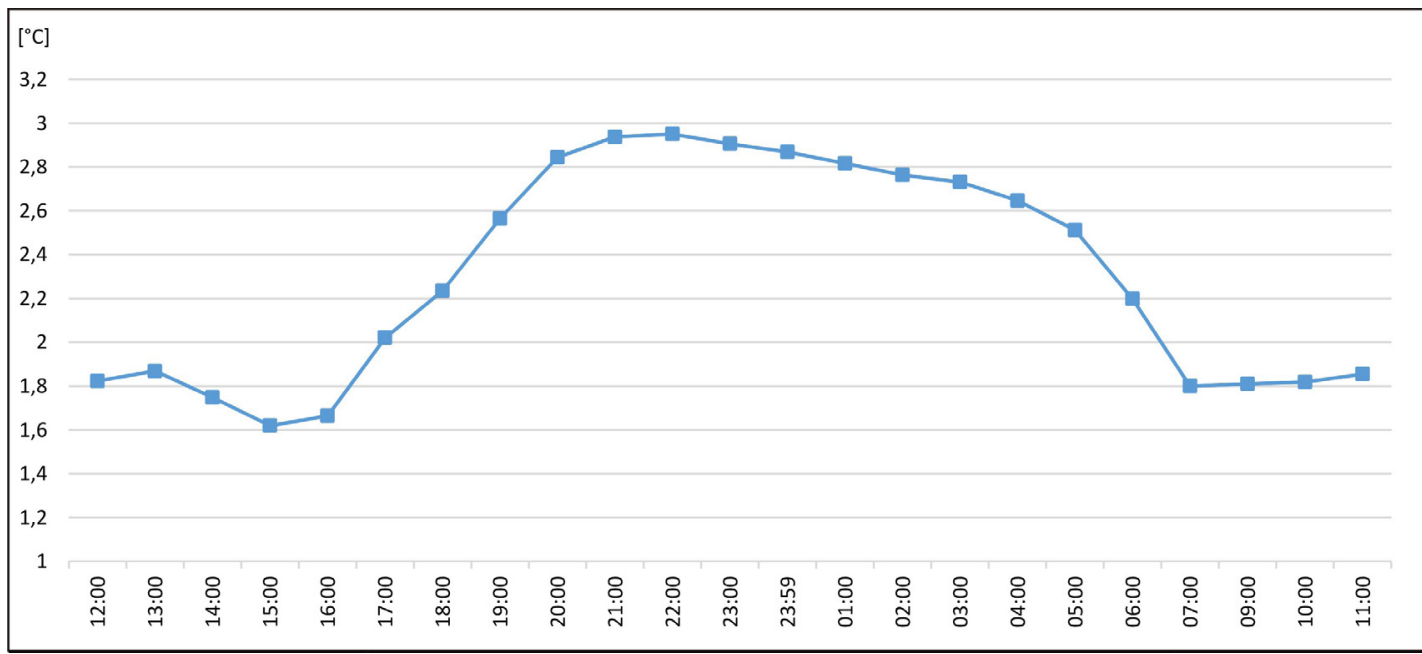

Figure 2. Daily course of the urban heat island in Białystok

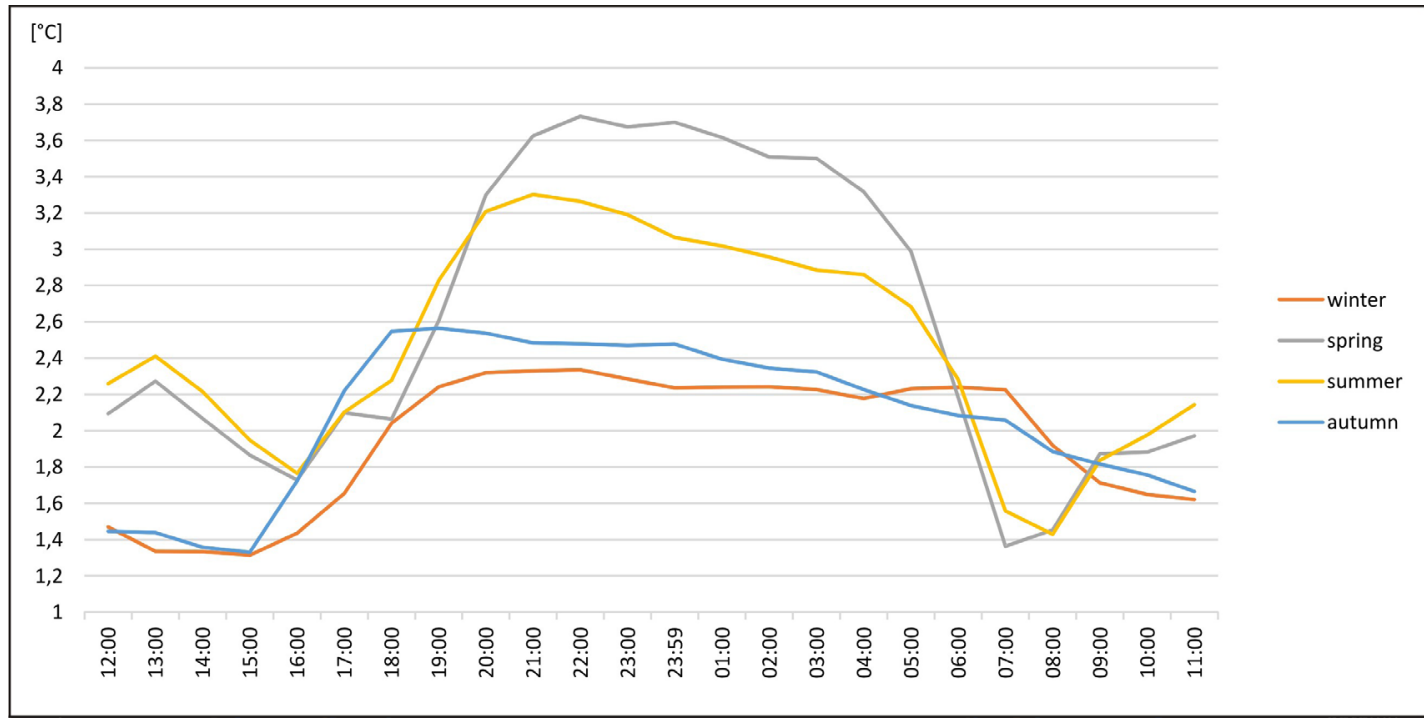

Figure 3. Daily course of the urban heat island in Bialystok in every seasons 


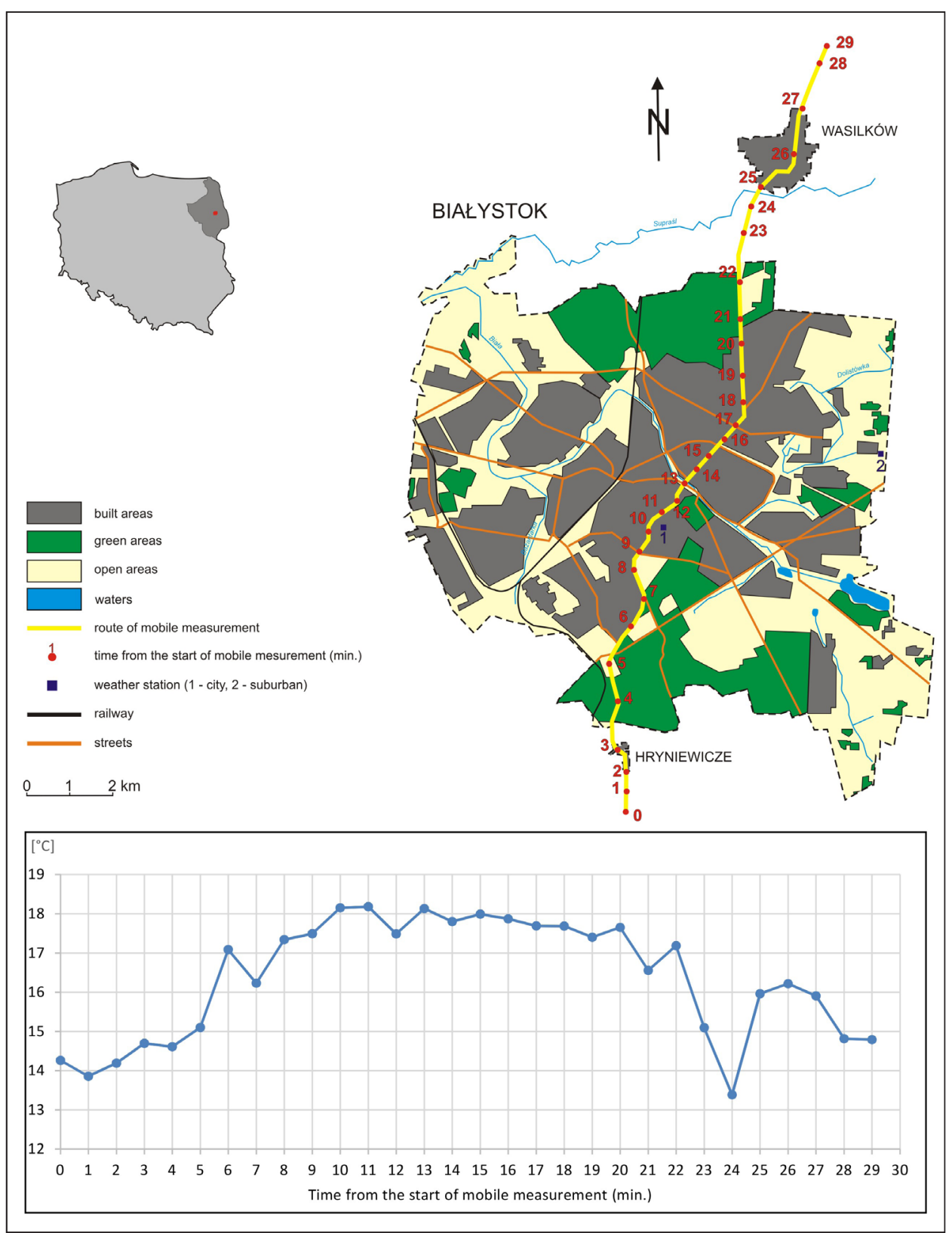

Figure 4. Measurement points at the area of Białystok

as wind speed increases, the temperature differential between urban and rural sites decreases asymptotically. A small wind speed and small clouds in summer are conducive to greater intensity of urban heat island at this part of the year [Gołaszewski et al. 2007]. The average winter temperature field is less diverse, because a strong wind persists often whole day.

\section{CONCLUSIONS}

Based on the analysis, the following conclusions can be expressed:
1. The phenomenon of urban heat island in Białystok is very clear and lasts throughout the year.

2. The maximum temperature differences measured between points located in the city center and its periphery occurred in the spring, and the lowest in winter.

3. The development of the urban heat island starts in the afternoon, reaching maximum in the late-evening hours.

4. Urban heat island depends on the land cover and is the most pronounced in the dense builtup city center. 


\section{Acknowledgements}

This work was financially supported by Ministry of Science and Higher Education as a part of the project $\mathrm{S} / \mathrm{WBiIS} / 01 / 14$.

\section{REFERENCES}

1. Asimakopoulos D.N. et al., 2001. Energy and climate in the urban built environment. James \& James, London, UK.

2. Błażejczyk K., Bakowska M., Więcław M., 2006. Urban heat Island in large and small cities. $6^{\text {th }}$ International Conference on Urban Climate, June 1216, Göteborg, Sweden.

3. Brazel, A., Selover, N., Vose, R., Heisler, G., 2000. The tale of two climates-Baltimore and Phoenix urban LTER sites. Climate Research 15, 123-135.

4. Chandler TJ. 1965. The Climate of London. Hutchinson: London.

5. Douglas, I., 1983. The urban environment. Edward Arnold, London.

6. Draxler R.R., 1986. Simulated and observed influence of the nocturnal urban heat island on the local wind field. J Climate Appl Meteor 25, 1125-1133

7. Emmanuel M.R., 2005. An urban approach to climate-sensitive design; Strategies for the tropics. Spon Press, London, UK.

8. Fan, H., Sailor, D.J., 2005. Modeling the impacts of anthropogenic heating on the urban climate of Philadelphia: a comparison of implementations in the two PBL schemes. Atmospheric Environment 39, 73-84.

9. Fortuniak K., Kłysik K., Wibig J., 2006. Urban-rural contrasts of meteorological parameters in Łódź. Theor. Appl. Climatol. 84, 91-101.

10. Gołaszewski D., Majewski G., Przewoźniczuk W., 2007. Oddziaływanie budownictwa kubaturowego i sztucznych źródeł ciepła na intensywność miejskiej wyspy ciepła w Warszawie. Architectura 6 (1).

11. Hawkins TW, Brazel AJ, Stefanov WL, Bigler W, Saffell EM. 2004. The role of rural variability in urban heat island determination for Phoenix, Arizona. Journal of Applied Meteorology 43, 476-486.

12. Hedquist BC, Brazel AJ. 2006. Urban, residential, and rural climate comparisons from mobile transects and fixed stations: Phoenix, Arizona. Journal of the Arizona-Nevada Academy of Science 38, 77-87.
13. Lakshmi, V., D. Zehrfuhs and T. Jackson, 2000. Observations of land surface temperature and its relationship to soil moisture during SGP99. In: Proc. IGARSS, 3, 1256-1258.

14. Landsberg H.E. 1981. The Urban Climate, vol. 28, InternationalGeophysics Series, Academic Press: New York.

15. Murphy D.J., Hall M.H., Hall C.A., Heisler G.M., Stehmana S.V. and Anselmi-Molinac C., 2011. The relationship between land cover and the urban heat island in northeastern Puerto Rico, Int. J. Climatol. 31, 1222-1239.

16. Nakamura Y, Oke TR. 1988. Wind, temperature and stability conditions in east-west oriented urban canyon. Atmos Environ 22, 2691-2700.

17. Oke T.R, East C. 1971. The urban boundary layer in Montreal. Boundary Layer Meteorology 1: 411-437.

18. Oke T.R. 1976. The distinction between canopy and boundary layer urban heat islands. Atmosphere 14, 268-277.

19. Oke, T.R. 1973. City size and the urban heat island. Atmospheric Environment 7, 769-779.

20. Oke, T.R., 1982. The energetic basis of the urban heat island. Quarterly Journal of the Royal Meteorological Society 108, 1-24.

21. Roth M. 2007. Review of urban climate research in (sub)tropical regions. International Journal of Climatology 27, 1859-1873.

22. Shaharuddin A., Noorazuan Md H., 2007. Effects of Soil Moisture on Urban Heat Island Occurrences: Case of Selangor, Malaysia, Humanity \& Social Sciences Journal 2 (2), 132-138.

23. Statistical Office in Białystok 2015. Social and Economic situation of Białystok in 2014, Białystok.

24. Strecker E., Liptan T., 2003. Ecoroofs (greenroof). A More sustainable infrastructure: Paper presented at the National Conference on Urban Stormwater: Enhancing Programs at the Local Level. February, Oregon.

25. Taha, H., Akbari, H., Rosenfeld, A., 1991. Heat Island and Oasis effects of vegetative canopies: micro-meteorological field measurements 44, 123-138.

26. Torok S, Morris C, Skinner C, Plummer N,. 2001, Urban heat island features of southeast Australian towns. Australian Meteorological Magazine 50 (1), 1-13. 